\title{
Chytrid infection in Asia: How much do we know and what else do we need to know?
}

\author{
Md. Mokhlesur Rahman ${ }^{1,2}$, Mahatub Khan Badhon1, Md. Salauddin³, Md. Fazle Rabbe ${ }^{1}$ \\ \& Md. Sirajul Islam ${ }^{1}$
}

\author{
'Department of Zoology, University of Dhaka, Dhaka 1000, Bangladesh \\ 2Department of Anthropology, Durham University, South Road, Durham DH1 3LE, UK \\ ${ }^{3}$ Department of Geography and Environment, Jagannath University, Dhaka 1100, Bangladesh
}

\begin{abstract}
We conducted a systematic review to evaluate the knowledge base for amphibian chytrid Batrachochytrium dendrobatidis $(B d)$ infection in the continent of Asia. Despite an indication of geographic bias in terms of studying chytrid fungus distribution in Asia, 167 amphibian species (145 spp. native to Asia) from 16 countries have been reported as infected with $B d$. Our meta-analysis shows that overall prevalence is $8.19 \%$ (out of 28,433 samples), and $B d$-positive rate in amphibia significantly varies among sampling sources $\left(\chi^{2}=380.57, D F=6, P<0.001\right)$ and age categories $\left(\chi^{2}=22.09, D F=2, P<0.001\right)$. We used Kernel Density analysis to produce a hotspot map for chytrid infection, and Digital Elevation Model to understand the distribution of chytrid positive locations across different elevations. In our meta-analysis, most of the $B d$-positive sites range between $4.45-27.49^{\circ} \mathrm{C}, 167-4,353 \mathrm{~mm}$ rainfall, $10-40^{\circ} \mathrm{N}$, and at lower elevations $(<500 \mathrm{~m})$. Using land cover analysis, we did not find a statistically significant difference among six different land cover categories in relation to the prevalence of $B d$ across Asia. Although no mass die-off events have been reported so far, Maximum Entropy modelling shows that $B d$ distribution and infection may potentially occur across a vast region of south-east Asia. In conclusion, we call for more systematic research and monitoring strategies in place for countries with little to no information, but have a moderately higher risk of chytrid distribution and infection.
\end{abstract}

Keywords: chytrid fungus, Batrachochytrium dendrobatidis, chytridiomycosis, emerging infectious disease, amphibian conservation, amphibian disease, Asia

\section{INTRODUCTION}

$\mathrm{C}^{\mathrm{n}}$ hytrid fungus, Batrachochytrium dendrobatidis (hereafter $B d$ ), causes chytridiomycosis disease; one of the greatest threats to global amphibian diversity (Bower et al., 2017; Gascon et al., 2007; Lötters et al., 2009; Skerratt et al., 2007; Vredenburg et al., 2010). This infectious disease, first reported in 1998 (Berger et al., 1998), is known to infect over 700 species and affect at least 501 species from multiple continents (Olson et al., 2013; Scheele et al., 2019).

Evidence supporting the connection between $B d$ infection and frog declines started unfolding from Australia (Woodhams \& Alford, 2005), Europe (Mutschmann et al., 2000), North America (Vredenburg et al., 2010), Central America (Lips et al., 2006, 2008; Woodhams et al., 2008) and Asia (Kusrini et al., 2008; Une et al., 2008). Since then, chytridiomycosis has been regarded as one of the most devastating diseases, causing events of mass mortality, population declines, and even extinction of amphibian populations around the world (Lips et al., 2006; Skerratt et al., 2007). Evidence also suggests that some amphibian populations survive beyond the initial outbreaks, and some with dramatically reduced abundances and distributions (Crawford et al., 2010; Vredenburg et al.,
2010). The cause of widespread and severe "enigmatic" declines in about $43 \%$ of all amphibian species around the world (Stuart et al., 2004) has now become obvious, and the fungus $B d$ has become a major conservation concern worldwide.

Despite $B d^{\prime}$ 's global distribution, significant loss of amphibian diversity has occurred within restricted geographic regions (Garner et al., 2005; Lips et al., 2006; Vredenburg et al., 2010). In Asia, Bd is a post-2007 phenomenon, with chytrid was first reported in December 2006 (published by Une et al. in 2008). However, a later study finds the presence of chytrid in a museum specimen of Andrias japonicas collected in 1902 (Goka et al., 2009). Compared to other continents, reports of chytrid in Asia (Bai et al., 2010; Kusrini et al., 2008; Mendoza et al., 2011; Nair et al., 2011; Parto et al., 2013; Rowley et al., 2013; Savage et al., 2011; Swei et al., 2011; Une et al., 2008; Voros et al., 2012; Yang et al., 2009) are comparatively recent, and severe declines of wild amphibian population have not been reported. This could be due to the lack of adequate and detailed research on $B d$ (Molur et al., 2015) and on amphibian demography in Asia (Lips, 2016). The dearth of information and the insidious nature (i.e. pathogenicity, epidemiology and possible impacts) of potential chytridiomycosis are of concern to amphibian 
conservation in Asia.

Despite no record of a chytridiomycosis epidemic leading to mass die-off of any amphibian population in Asia, $B d$ has been detected both in native and exotic amphibian species at a relatively low prevalence. Several studies (Lötters et al., 2009; Puschendorf et al., 2009; Rödder et al., 2009; Ron, 2005; Swei et al., 2011) have used different environmental factors to model the distribution of $B d$ in Asia. The results suggest that $B d$-suitable conditions exist across Asia. Suitable environmental conditions, however, do not guarantee the occurrence of $B d$ because dispersal and persistence also play a crucial role. Evidence has been gathered in support of both a 'novel pattern hypothesis', i.e. $B d$ spreads anthropogenically, and is an 'endemic pathogen hypothesis', i.e. $B d$ is endemic (Goka et al., 2009). Ecological factors and the combination of both hypotheses are required to comprehensively explain the known distribution of $B d$ in Asia.

From an ecological perspective, the spatial distribution of a pathogen is important to understand its pathogenicity, prevalence and epidemiology. The applicability of remote sensing and Geographical Information System (GIS) as tools to study species epidemiology have allowed researchers to understand disease occurrence and contributing environmental factors (Rytkönen, 2004). Previous reviews on the epidemiology of chytridiomycosis (Fisher, 2009; Skerratt et al., 2007) provide a comprehensive global overview; however, the localised perspective of Asia remains masked owing to a lack of data from Asia, compared to the plethora of information from other continents. However, spatial analysis has often been applied for epidemiological studies in a data-poor context (Graham et al., 2004).

Here we conducted a systematic review and metaanalysis of existing information and presented a comprehensive overview on chytrid infection in Asia. With an aim to evaluate the current knowledge base, we have framed this review to answer the following questions;

i) How does the research effort on $B d$ vary a spatial and temporal scale within Asia?

ii) What is the prevalence of chytrid in different amphibian species and Asian countries?

iii) What is the difference in $B d$ prevalence across different sources (wild, pet store, food market, etc.) and age categories (adult, juvenile and tadpole) of amphibian samples?

iv) What is the spatial distribution of chytrid hotspots in Asia (based on existing data for $B d$-positive localities)?

v) What is the range of environmental and geographical factors (e.g. land cover, temperature, rainfall, elevation and latitude) for $B d$-positive localities in Asia?

vi) How could $B d$ potentially spread or distribute in Asia?

\section{METHODS}

\section{Literature search protocol and data collection}

To compile all the relevant literature published between 2007 and 2018 on chytrid infection in Asia, we made a comprehensive search in Google Scholar, PubMed, PubMed Central and ResearchGate using keywords such as, 'chytridiomycosis in Asia', 'Batrachochytrium dendrobatidis in Asia', 'chytrid fungus infection', 'Bd haplotypes', and other combinations of these keywords. We screened titles, abstracts and keywords of papers that are found from these searches to determine literature relevant to chytrid and its infection within Asia. We also conducted a snowball sampling of the bibliographic section of papers to find new papers that were missing from the search made with the abovementioned keywords. Our selection protocol resulted in 53 articles for the review, of which 50 were peer-reviewed journal articles and three were conference papers (see Supplementary Material 1).

We have used 'literature', 'paper', and 'publication' interchangeably; however, we made a distinction between these words and 'study'. For example, when a paper deals with samples from several Asian countries, we treated each country as an individual study for the convenience of data handling and analysis. Therefore, one 'paper' or 'publication' may represent one or several 'studies'. The age of each sampled species was considered as adult unless otherwise mentioned in the paper. All data described in Table 1 were collected for each country and amphibian species studied for $B d$ infection across Asia. To conduct the meta-analysis, each publication was carefully read and data were extracted to address the questions asked in this review.

Table 1. Different data extracted from publications to address questions set for the review.

\begin{tabular}{|c|c|c|}
\hline $\begin{array}{l}\text { Data } \\
\text { types }\end{array}$ & $\begin{array}{l}\text { To address questions } \\
\text { posed in Introduction }\end{array}$ & $\begin{array}{c}\text { Outcomes of } \\
\text { corresponding analysis }\end{array}$ \\
\hline $\begin{array}{l}\text { a) Number and corresponding } \\
\text { year of peer-reviewed } \\
\text { literature relevant to } \\
\text { chytridiomycosis in Asia } \\
\text { between } 2007 \text { and } 2018 \\
\text { b) Asian countries sampled to } \\
\text { investigate chytrid infection }\end{array}$ & (i) & $\begin{array}{l}\text { a) The trend of } B d \\
\text { related research efforts } \\
\text { in Asia both at spatial } \\
\text { and temporal scale }\end{array}$ \\
\hline $\begin{array}{l}\text { c) Amphibian species sampled } \\
\text { to investigate chytrid infection }\end{array}$ & & $\begin{array}{l}\text { b) Number of native and } \\
\text { exotic amphibian species } \\
\text { infected by } B d \text { in Asia }\end{array}$ \\
\hline $\begin{array}{l}\text { d) Volume of samples } \\
\text { collected and test results from } \\
\text { each country and per species }\end{array}$ & (ii) & $\begin{array}{l}\text { c) Prevalence of chytrid } \\
\text { infection in different } \\
\text { species and countries } \\
\text { across Asia }\end{array}$ \\
\hline $\begin{array}{l}\text { e) Total number of amphibian } \\
\text { samples collected from } \\
\text { different sources and age } \\
\text { categories }\end{array}$ & (iii) & $\begin{array}{l}\text { d) Understanding of the } \\
\text { trend of chytrid infection } \\
\text { in amphibians from } \\
\text { different sources and age } \\
\text { categories }\end{array}$ \\
\hline $\begin{array}{l}\text { f) Localities of } B d \text {-positive } \\
\text { reports and number of } \\
\text { positive and negative samples } \\
\text { of that corresponding } \\
\text { localities across Asia }\end{array}$ & (iv) & $\begin{array}{l}\text { e) Understanding the } \\
\text { hotspots for } B d \text { infection } \\
\text { across Asia }\end{array}$ \\
\hline $\begin{array}{l}\text { g) Environmental factors } \\
\text { (temperature and rainfall) } \\
\text { form } B d \text {-positive localities } \\
\text { within Asia } \\
\text { h) Geographical factors (land } \\
\text { cover, elevation and latitude) } \\
\text { from } B d \text {-positive localities } \\
\text { within Asia }\end{array}$ & (v) & $\begin{array}{l}\text { f) Suitable range of } \\
\text { environmental and } \\
\text { geographical factors for } \\
B d \text { infection in Asia }\end{array}$ \\
\hline $\begin{array}{l}\text { i) Bioclimatic variables ( } n=19 \text { ) } \\
\text { of } B d \text {-positive localities within } \\
\text { Asia }\end{array}$ & (vi) & $\begin{array}{l}\text { g) Future potential } \\
\text { distribution of } B d \text { across } \\
\text { Asian regions }\end{array}$ \\
\hline
\end{tabular}




\section{GIS database preparation and analysis}

From the selected literature, we gathered 209 Bdpositive locations across Asia. The positive locations are more in number but we did not extract data from papers that did not provide any coordinates. In papers where the coordinates of positive localities were mentioned, we directly extracted those. In papers where positive locations were shown only in a map, we georeferenced the map and extracted the coordinates of $B d$-positive locations. In few cases, we failed to extract exact locations from the study map without coordinates, and so we contacted the corresponding author of those papers to ask for the positive site locations. We extracted the elevation data for every point location using Global Multiresolution Terrain Elevation Data 2010 (GMTED2010; downloaded from EROS; https://earthexplorer.usgs.gov). From the downloaded GMTED Digital Elevation Model, we used mosaic (ArcGIS software setting the parameter for projection system as WGS_1984_World_Mercator and pixel type as 16-bit signed integer) to obtain a single image. We used "extract multi values to point" tool in ArcGIS software to extract elevation for all point locations. We also employed Kernel Density in ArcGIS software to identify the hotspots of likely $B d$ occurrence (Silverman, 1986). We did not consider $B d$-positive locations without having exact data on sample size and $B d$-positive records in that respective location, hence we selected $193 B d$ positive locations for Kernel Density analysis. In few papers, amphibian sample size was available without any

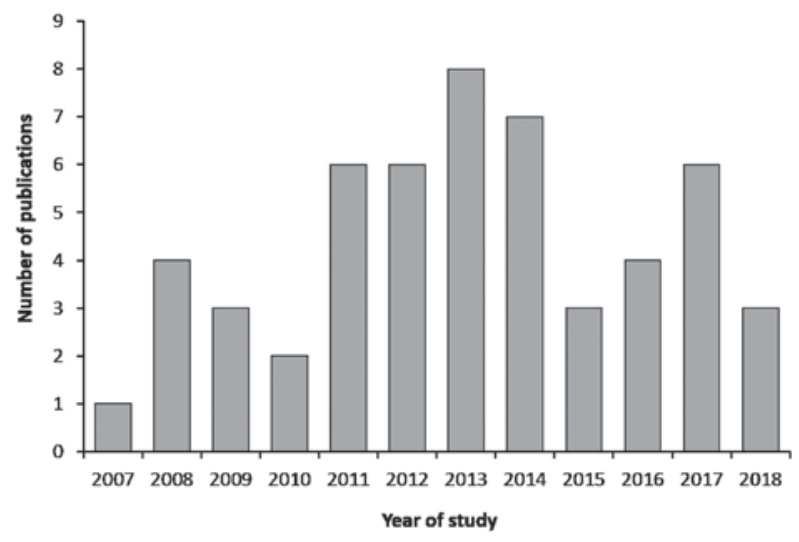

Figure 1. Total number of articles relevant to chytrid infection in Asia published per year between 2007 and 2018. Literature searches resulted into 53 articles, of which 50 were peer-reviewed articles and three were conference papers. The most number of articles were published in 2013.

specific location - just mentioning the name of city or state. For such cases, we set a point where most samples were taken from that corresponding city or state and used that for all respective samples. We performed maximum entropy (Maxent) modelling for $B d$ distribution (Phillips et al., 2006). To perform the distribution modelling, we downloaded 30 arc seconds $\left(\sim 1 \mathrm{~km}^{2}\right)$ resolution bioclimatic variables data in raster format from WorldClim

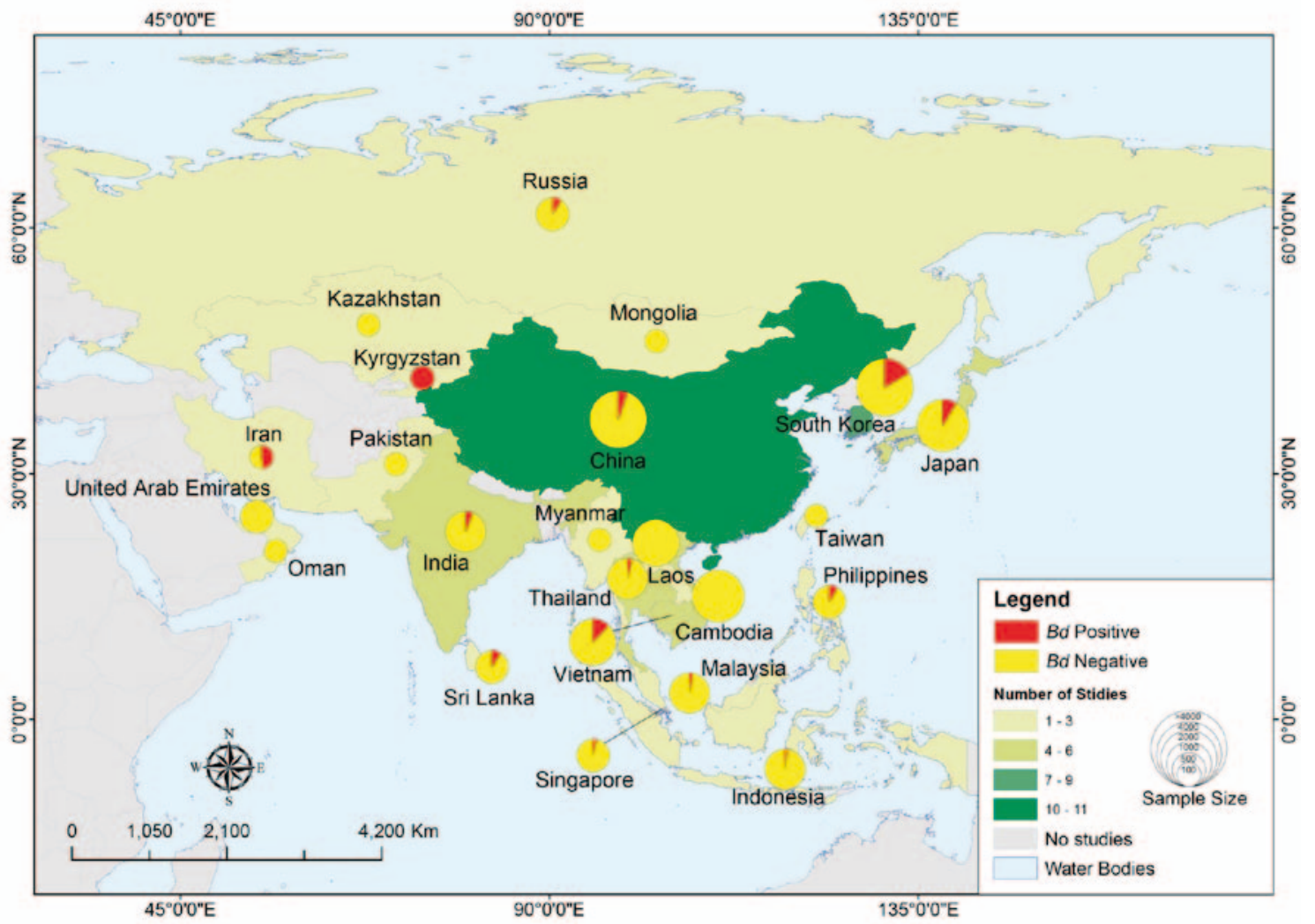

Figure 2. Number of studies conducted in different countries across Asia between 2007 and 2018. When we found a published article dealing with samples from several countries, we treated each country as a separate study for the convenience of data handling and analysis. Chytrid was most studied in China within this period of time. It should be noted that data from Taiwan were treated separately to China. Pie chart to each corresponding country represents the prevalence data of chytrid infection. 
version2 (http://worldclim.org/version2) (Global Climate Data) (Fick \& Hijmans, 2017). Country boundaries were downloaded from the GADM (Database of Global Administrative Areas) website to show the study area boundary. Downloaded raster data were pre-processed in ArcGIS software using SDM toolbox, downloaded from http://sdmtoolbox.org (Brown, 2014). Downloaded raster data were clipped by masking from the SDM toolbox using the study area shapefile. The clipped raster was then converted in ASCII format and the projection of converted ASCII raster data were set as WGS84. The occurrence dataset was prepared in csv format using MS Excel software converted to shapefile using csv to shapefile setting the projection as WGS84. The effects of spatial clusters of localities were reduced by spatially rarefying the occurrence dataset. The 30 arc second resolution coordinate bias dataset were downloaded (http:// sdmtoolbox.org) to fit the model. Maxent modelling software (Version 3.4.1) was downloaded (accessed on 8 May 2019) in jar format from American Museum of Natural History (https://biodiversityinformatics.amnh. org/open_source/maxent).

The Maxent modelling is a probability statistic that is calculated based on the existing location correlated with the bioclimatic variables. However, the probability statistic does not mean that the higher level of probability will surely ensure $B d$ presence; rather it denotes strong possibility of having $B d$ infection, and vice versa. Kernel Density calculation represents the density of the existing occurrence, and Maxent modelling forecasts the possible location of $B d$ occurrence.

We conducted a land cover analysis to see whether $B d$ prevalence varies in different land cover patterns. To do this, we extracted the land cover information of sampling sites from the reviewed articles; if it was not mentioned we extracted manually, placing all the sampling points in Google Earth at a higher resolution ( $5 \mathrm{~m}$ zooming scale). We divided land cover into six categories, i.e. agriculture, fallow land, forest, vegetation, water bodies and builtup. We did not consider the positive locations/points for this analysis without having prevalence data on that corresponding point. Therefore, the analysis was conducted on 182 points. The most recent land cover information has been considered because not all the locations have time series data in Google Earth.

We performed Chi-square $\left(\chi^{2}\right)$ analysis to understand whether $B d$ prevalence rate varied based on different sources and age categories. A non-parametric KruskalWallis test was used to analyse significant differences in prevalence among different land cover categories. We also used post-hoc tests to compare difference between two categories. We conducted all statistical tests using $\mathrm{R}$ version 3.5.1 (R Development Core Team, 2018).

\section{RESULTS}

\section{Research efforts on amphibian chytrid in Asia}

Amphibian chytrid fungus research in Asian countries has been consistent since its discovery. The number of scientific articles published between 2007 and 2018 does not exceed eight articles in any year (Fig. 1). These studies are spread across 23 countries (out of 49 Asian countries;
Taiwan has been considered as a separate country for the convenience of analysis). It is notable that six countries (i.e. Cambodia, China, Japan, South Korea, Thailand and Vietnam) represent $60 \%$ of the total studies conducted in Asia (Fig. 2). Other Asian countries (except for Cambodia, China, Japan, South Korea, Thailand and Vietnam) have fewer than three or no studies on $B d$ infection on amphibians.

\section{Prevalence of chytrid infection in Asia}

A meta-analysis shows that $8.19 \%$ samples (out of 28,433 samples) were $B d$-positive (Table 2 ). Regardless of sample size investigated per country, country-wise prevalence rate shows that Kyrgyzstan has the highest rate (100\%), followed by Iran (47.25\%), South Korea (16.39\%), and Cambodia (12.04\%). The rest of the 19 countries have a prevalence rate below $10 \%$, Laos being the lowest $(0.24$ $\%)$.

Across the published literature, samples were taken from seven different sampling sources (i.e. wild, food market, commercial farm, pet store, zoo and aquarium, preserved, and imported specimens) to evaluate the prevalence of $B d$. The proportion test suggests that the $B d$-positive rate for each sampling source significantly differs $\left(\chi^{2}=380.57, D F=6, P<0.001\right)$ from other sampling sources. Post-hoc pairwise comparison shows that pet store frogs have significantly higher $B d$ prevalence than all other sources ( $P<0.01$ for each comparison). Likewise, statistical test reveals that the $B d$-positive rate in each age category (i.e. adult, juvenile and tadpole) significantly differs $\left(\chi^{2}=22.09, D F=2, P<0.001\right)$ from others, though none of pairwise comparison shows significant difference (Table 3).

\section{Impact of $B d$ on amphibian species in Asia}

At least 167 amphibian species (146 anurans, 17 urodeles, and four caecilians) belonging to 27 families (19 anurans, seven urodeles, and one caecilian) from 16 Asian countries have been reported to be infected with $B d$. The number of infected species is subject to change (likely to be higher) because many positive samples came from animals of unresolved taxonomic status (e.g. Ceratophrys sp., Fejervarya sp., Limnonectes sp., Leptolalax sp., Megophrys sp., Leptobrachium sp., Microhyla sp., Xenophrys sp., Odorrana sp., Gracixalus sp., Kurixalus sp., Philautus sp., Rhacophorus sp., Telmatobius sp., Ambystoma sp. (Supplementary Table S1). Of Bdpositive amphibian species, 145 species were native and remaining 22 species were either introduced or traded from Africa, Europe and South America for research or commercial purposes. Without accounting for sample size and the number of amphibian species tested for $B d$, our analysis shows that Japan has the highest number of species (40) infected with $B d$, followed by China (32), India (23), South Korea (16), Cambodia (16), Malaysia (12) and Indonesia (9) (Supplementary Table S1).

\section{Suitable range of geographical and environmental factors for $B d$ infection}

The Digital Elevation Model suggests that $B d$-positive sites are distributed between 0 and 2,701 $\mathrm{m}$ above sea level (Fig. 3 ); however, with the increasing elevation, the number of 


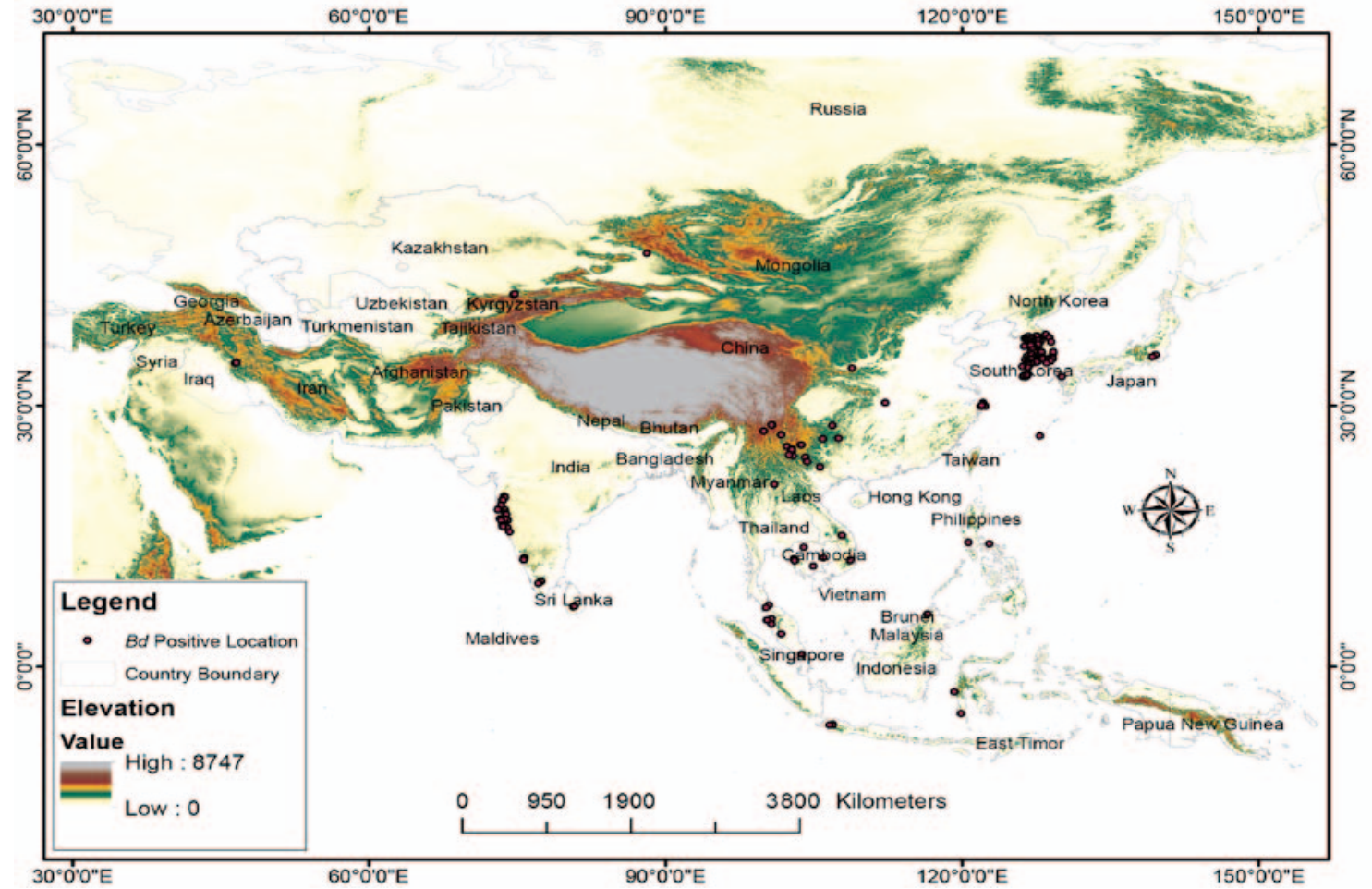

Figure 3. Relationship between elevation and positive localities for $B d$ infections within Asia using Digital Elevation Model. We gathered 209 Bd-positive locations across Asia from the selected literatures. Elevation for every point location was extracted from Global Multi-resolution Terrain Elevation Data 2010, downloaded from EROS (https://earthexplorer.usgs.gov).

Table 2. Percentage of $B$. dendrobatidis infection in Asian countries (samples were taken from wild or natural habitat, pet shops and food markets, commercial farms, zoos and aquariums, imported individuals, and historical samples preserved in museums). The Clopper Pearson binomial confidence intervals (95\%) were calculated using the R package PropCls in $\mathrm{R}$ 3.5.1 version.

\begin{tabular}{|c|c|c|c|c|c|c|}
\hline Sub-regions & Country & $\begin{array}{l}\text { Year of first } \\
\text { publication }\end{array}$ & Samples tested & Bd positive & Prevalence (\%) & $\begin{array}{c}95 \% \text { Confidence } \\
\text { interval }\end{array}$ \\
\hline \multirow[t]{2}{*}{ Central Asia } & Kazakhstan & 2011 & 4 & 0 & - & $0-60.24$ \\
\hline & Kyrgyzstan & 2011 & 9 & 9 & 100.00 & 66.37- 100 \\
\hline \multirow[t]{5}{*}{ East Asia } & China & 2007 & 7645 & 409 & 5.35 & $4.86-5.88$ \\
\hline & Japan & 2008 & 3640 & 308 & 8.46 & $7.58-9.41$ \\
\hline & Mongolia & 2011 & 23 & 0 & - & $0-14.82$ \\
\hline & South Korea & 2009 & 7411 & 1215 & 16.39 & $15.56-17.26$ \\
\hline & Taiwan & 2008 & 20 & 0 & - & $0-16.84$ \\
\hline \multirow[t]{3}{*}{ South Asia } & India & 2011 & 821 & 47 & 5.72 & $4.24-7.54$ \\
\hline & Pakistan & 2011 & 5 & 0 & - & $0-52.18$ \\
\hline & Sri Lanka & 2011 & 117 & 10 & 8.55 & $4.17-15.16$ \\
\hline \multirow[t]{9}{*}{ South-east Asia } & Cambodia & 2011 & 1213 & 146 & 12.04 & $10.26-14$ \\
\hline & Indonesia & 2008 & 955 & 17 & 1.78 & $1.04-2.83$ \\
\hline & Laos & 2011 & 1677 & 4 & 0.24 & $0.06-0.61$ \\
\hline & Malaysia & 2011 & 578 & 13 & 2.25 & $1.2-3.81$ \\
\hline & Myanmar & 2011 & 62 & 0 & - & $0-5.78$ \\
\hline & Philippines & 2011 & 412 & 34 & 8.25 & $5.78-11.34$ \\
\hline & Singapore & 2013 & 419 & 13 & 3.10 & $1.66-5.25$ \\
\hline & Thailand & 2008 & 785 & 25 & 3.18 & $2.07-4.67$ \\
\hline & Vietnam & 2011 & 2133 & 15 & 0.70 & 0.39-1.16 \\
\hline \multirow{3}{*}{$\begin{array}{l}\text { South-west Asia } \\
\text { (Middle-east Asia) }\end{array}$} & Iran & 2013 & 91 & 43 & 47.25 & $36.69-57.99$ \\
\hline & Oman & 2016 & 60 & 0 & - & $0-5.96$ \\
\hline & United Arab Emirates & 2012 & 103 & 0 & - & $0-3.52$ \\
\hline \multirow[t]{2}{*}{ North Asia } & Russia & 2013 & 250 & 22 & 8.80 & 5.59-13.02 \\
\hline & Total & & 28433 & 2330 & 8.19 & $7.88-8.52$ \\
\hline
\end{tabular}


A

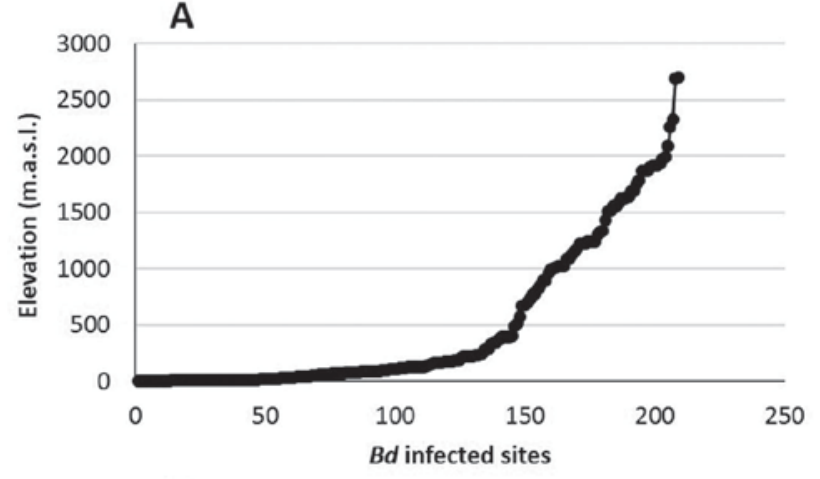

C

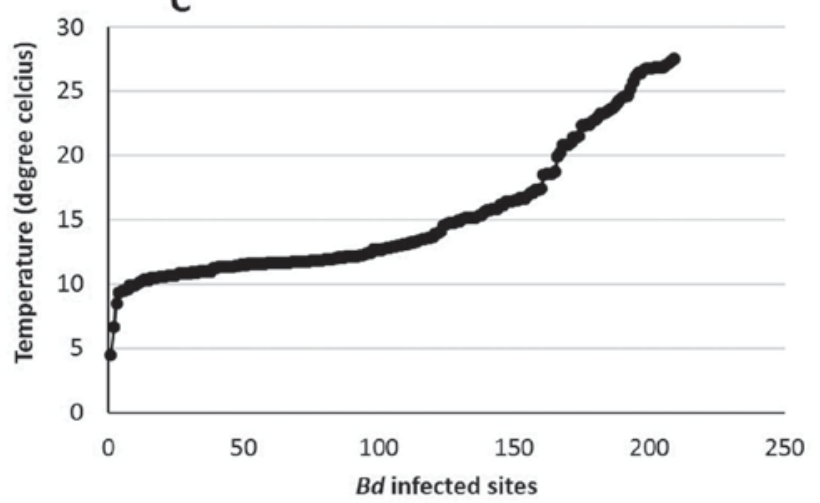

B
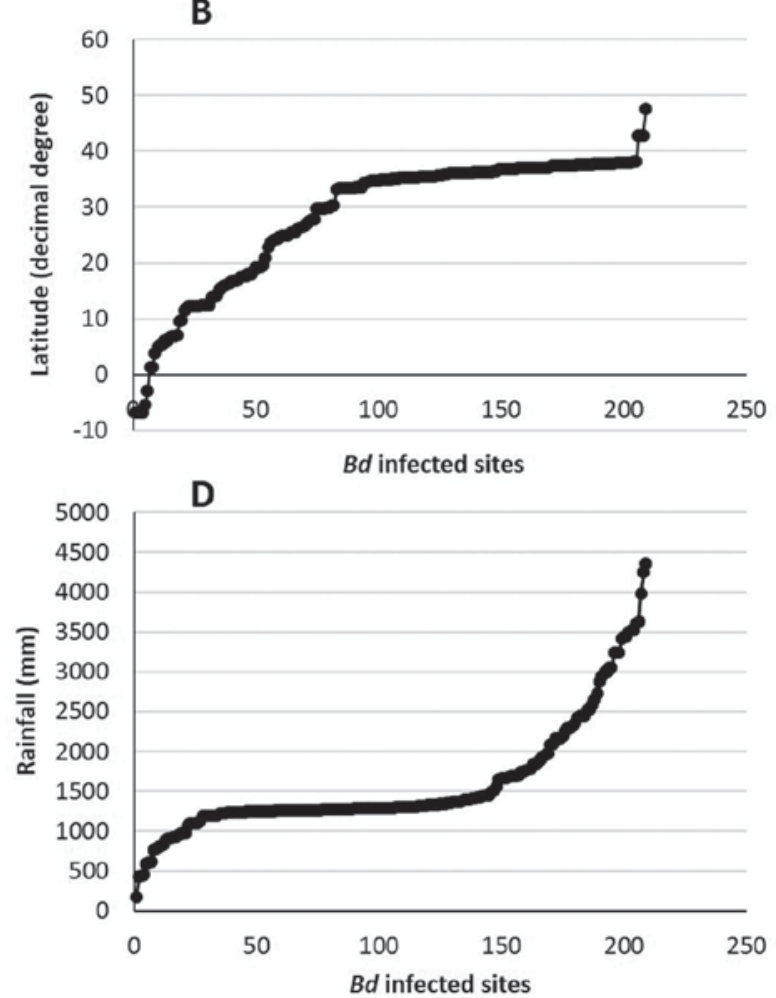

Figure 4. Bd-infected sites within Asia in different elevation (A), latitude (B) temperature (C) and rainfall (D).

$B d$-positive sites decreases. The data set shows that more than two thirds (146 occurrences) of chytrid infected sites are below 500 m elevation followed by 14 occurrences between 500 and 1,000 $\mathrm{m}$ and 44 occurrences between the elevations of 1,001 and 2,000 m (Fig. 4A), suggesting that $B d$ is more widespread at lower elevations $(<500$ $\mathrm{m}$ above sea level). Our analysis also reveals that nearly $90 \%$ (185 occurrences) of $B d$-positive sites are located between $10^{\circ} \mathrm{N}$ to $40^{\circ} \mathrm{N}$ (Fig. 4B), suggesting a high risk area for $B d$ infection. The temperature of $B d$-positive sites fell between $4.45^{\circ} \mathrm{C}$ and $27.49^{\circ} \mathrm{C}$, where about 62 $\%$ of infected sites had temperatures of $15^{\circ} \mathrm{C}$ or below, and $80 \%$ sites were below $20^{\circ} \mathrm{C} \mathrm{(Fig.} 4 \mathrm{C}$ ). Annual rainfall of $B d$-positive sites ranged between $167 \mathrm{~mm}$ and 4,353 $\mathrm{mm}$ (Fig. 4D). It is notable that $70 \%$ of $B d$ infected sites were located in regions with rainfall between 1,001 and $2,000 \mathrm{~mm}$, and about $83 \%$ infected sites are located in rainfall regions between 1,001 and 3,000 mm (Fig. 4D). Only about $10 \%$ of infected sites were in regions with rainfall below $1,000 \mathrm{~mm}$ and $2 \%$ of sites had rainfall of $500 \mathrm{~mm}$ or less.

Our analysis of $B d$-positive sites shows that $B d$ prevalence does not significantly differ among different land cover patterns (Kruskal-Wallis Test, $\chi^{2}=5.88, D F=$ $5, P>0.05)$. Post-hoc pair-wise comparison also shows that prevalence does not significantly differ between any two land cover categories. However, prevalence is slightly higher in fallow land than other categories. A maximum of $100 \%$ prevalence was found in every land cover category except for 'vegetation' (Fig. 5).

\section{Hotspot analysis for $B d$ infection in Asia}

According to our spatial hotspot analysis, $B d$ prevalence

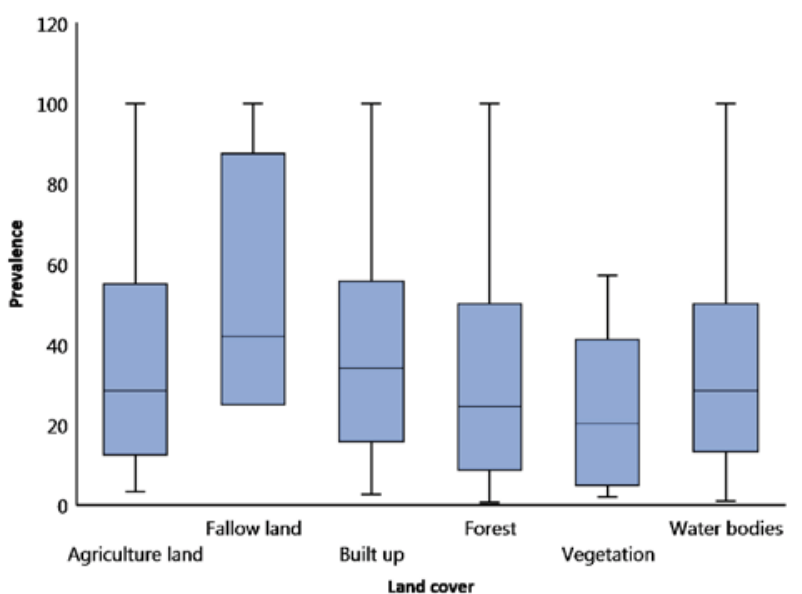

Figure 5. $B d$ prevalence in different land cover categories; quartile 2 and 3 are shaded with the dividing line as median, whiskers indicate quartile 1 and 4 . Land cover information was extracted manually from Google Earth at $5 \mathrm{~m}$ zooming scale when land cover of sampling sites was not mentioned in the respective paper. We only used $B d$-positive point locations (182 in this case) that have prevalence data on that corresponding point.

rate in $B d$-positive localities was higher in the Korean peninsula, Japan, Thailand, Vietnam, Cambodia, the southern part of China; and moderately higher infection rates were observed in Sri Lanka, Singapore, Indonesia, southwestern part of India, and the northwestern part of Iran, Philippines and Malaysia (Fig. 6). 


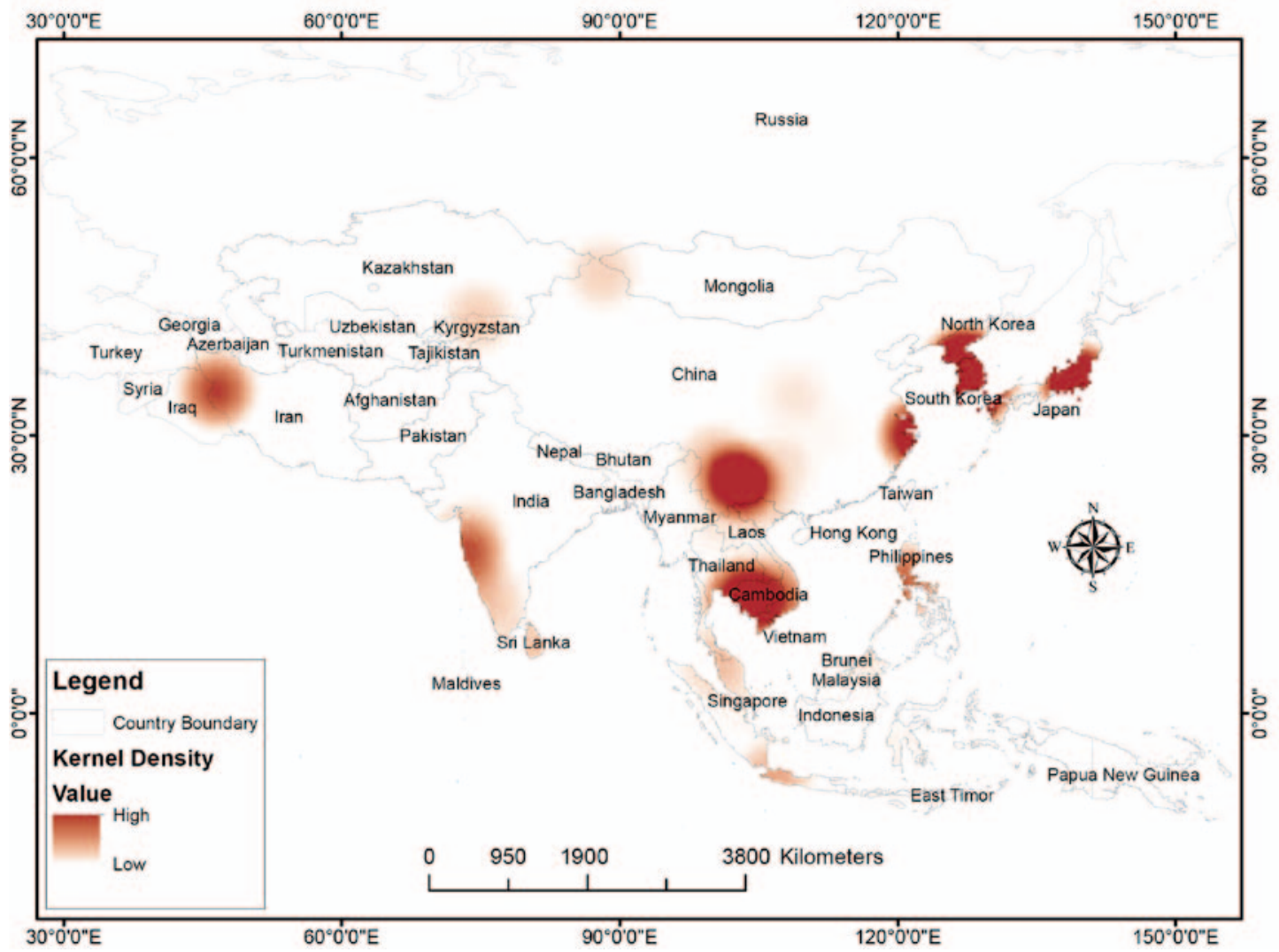

Figure 6. Kernel Density analysis based on $B d$-positive sites highlights the hotspots for $B d$ infection in Asia. We used $B d$ positive locations that have confirmed $B d$-prevalence data, along with some points without specific coordinate locations only mentioning the city or state as the study area. In those cases, we set a point where most samples were taken from that corresponding city or state and used this point for all respective samples, resulting in 193 positive points for this analysis.

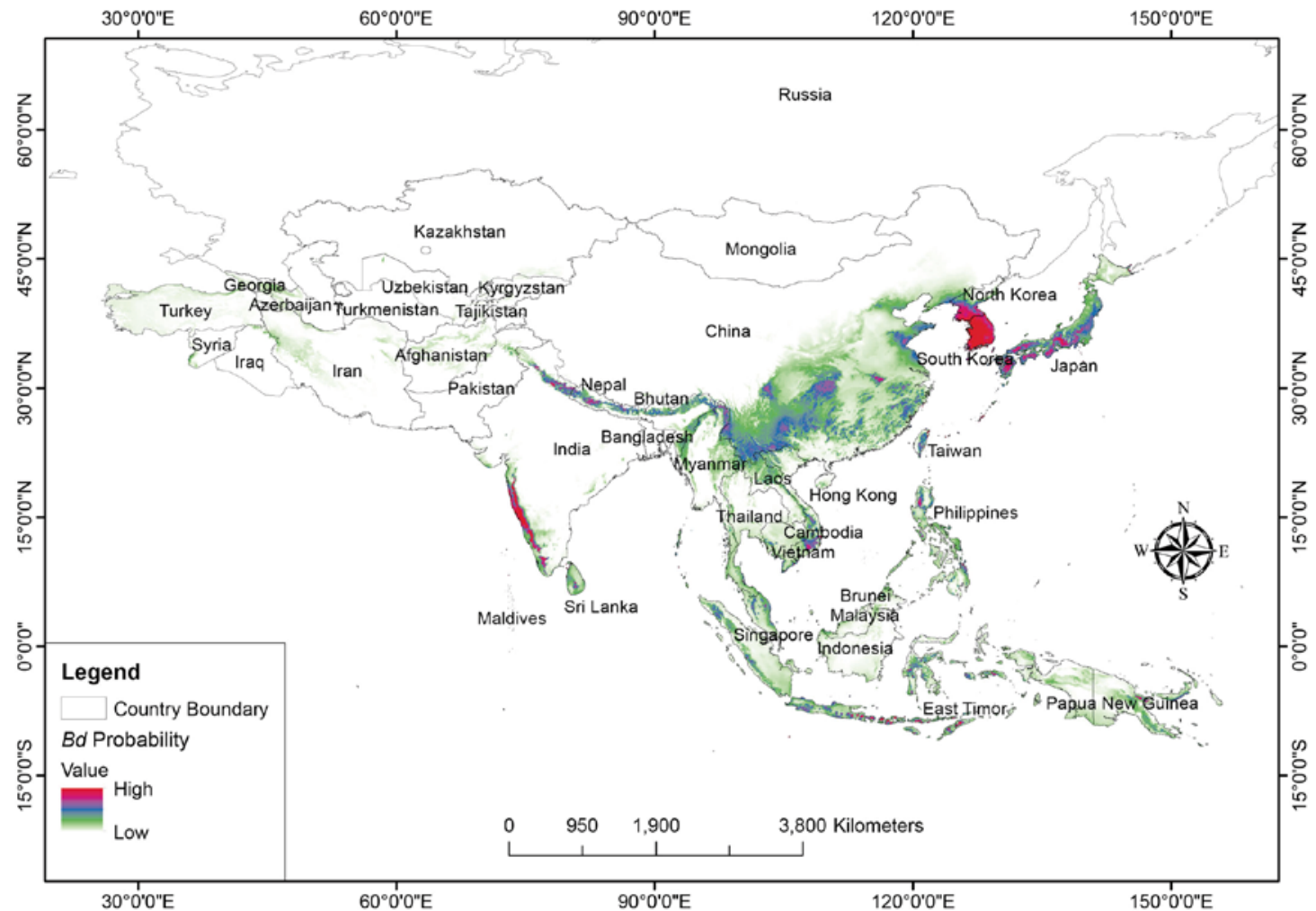

Figure 7. Potential distribution of $B d$ infection in Asia based on Maximum Entropy Modelling. We used 30 seconds ( 1 $\mathrm{km}^{2}$ ) resolution bioclimatic data that was downloaded from WorldClim version2 (http://worldclim.org/version2) for the model. 30 arc second resolution coordinate bias dataset was also downloaded from http://sdmtoolbox.org to fit the model. 


\section{Probability of $B d$ distribution in Asia}

The Maxent modelling showed the probability of $B d$ infection based on the existing infected locations (Fig. 7). Korea, Japan, the Western Ghats of India, and southern part of Indonesia had a higher probability of $B d$ infection. The Himalayan mountainous region also showed a moderate level of probability of $B d$ infection. The results showed that the oriental region and the south-eastern part of China have a moderate probability of having $B d$ infection.

\section{DISCUSSION}

\section{Research gaps on $B d$ in Asia}

The continent of Asia represents a significant portion of global amphibian diversity and a high level of endemism, however lesser focus has been put on the emergence of chytrid in this region compared to Australia, Europe, South and North America (Swei et al., 2011). The number of relevant journal articles (i.e. 53) in Asia are meagre considering the potential threat that chytrid fungus poses to amphibian populations worldwide. The geographic bias in survey effort is clearly evident (Fig. 2) from this review, where countries with no and limited investigation on $B d$ in Asia have been identified. Despite the reported cases of $B d$ infection in wild and captive amphibian populations from different Asian countries (Bai et al., 2010, 2012; Bataille et al., 2013; Dahanukar et al., 2013; Goka et al., 2009; Kusrini et al., 2008; Savage et al., 2011; Swei et al., 2011; Une et al., 2008; Yang et al., 2009; Zhu et al., 2014b), extensive areas of central, northern, and western mainland Asia still lack information on the presence and impacts of $B d$ (Olson et al., 2013; Olson \& Ronnenberg, 2014). Consistent with this view, our analysis shows that sites of interest chosen by researchers are geographically sporadic in distribution-highly concentrated in the Korean Peninsula, Japan, south-east Asia, southern part of China and south-western part of India. The sporadic geographic distribution of positive records may result from the lack of search and research efforts rather than a true absence of $B d$ in Asia (Yang et al., 2009).

Although $B d$ research is slowly gaining traction in different countries across Asia, some countries, such as Afghanistan, Bangladesh, Bhutan, Nepal and North Korea lack any studies (Fig. 2, up to June 2018). Geographic bias within countries is also evident. In China, $B d$ has been reported from 10 central and southern provinces of the country (Bai et al., 2010, 2012; Zhu et al., 2014a, b), with northern regions remaining poorly surveyed for the occurrence of this emerging disease. For India, only the south-western part of country has been surveyed, while no investigation has targeted the northern and eastern parts despite high amphibian diversity and abundance. The current lack of $B d$ research has implications for amphibian conservation in Asia. A lack of information limits our ability to resolve the origins of $B d$ and to understand its pathogenicity, and potential threats to native Asian amphibian populations.

We reviewed and expressed concerns about whether sample size, frequency, and timing was sufficient to accurately represent the prevalence of $B d$. Speciesspecific responses to $B d$ infection and a lower level of susceptibility to clinical chytridiomycosis (Retallick et al., 2004) can make the duration of infection longer and prevalence higher (Nelson \& Williams, 2014). Therefore, follow-up surveys of species from the same sites are critical to understanding the prevalence of $B d$ infection. A sample size that reflects the amphibian population in question is also crucial in this pursuit; our review shows that more than $60 \%$ of species (out of 167) surveyed for $B d$ in Asia had a sample size equal to or less than 30 (Supplementary Table S1). Our analysis of country-wide prevalence rate shows the need for more investigation with larger sample sizes. For example, Kyrgyzstan has $100 \%$ prevalence rate but only nine samples were tested (Swei et al., 2011). Similarly, in Iran $47 \%$ of samples tested $B d$-positive where the sample size was 91 (Table 2). Countries with a sample size of 100 or more reveal a prevalence rate lower than $17 \%$ regardless of the number of species sampled (Table 2). Our analysis also shows that the prevalence rate was almost double in tadpoles and juveniles than in adults (Table 3). However, compared to adults the sample size of other two age categories was negligible to draw any conclusion about actual prevalence rate and susceptibility to $B d$ infection.

Table 3. Percentage of Batrachochytrium dendrobatidis positive samples from different sources and age categories.

\begin{tabular}{ccccccc}
\hline $\begin{array}{c}\text { Source of } \\
\text { sample }\end{array}$ & $\begin{array}{c}\text { Sample } \\
\text { tested }\end{array}$ & $\begin{array}{c}\text { Bd } \\
\text { positive }\end{array}$ & $\%$ & $\begin{array}{c}\mathbf{X}^{2} \\
\text { Test }\end{array}$ & DF & $\begin{array}{c}\mathbf{P} \\
\text { value }\end{array}$ \\
\hline $\begin{array}{c}\text { Wild } \\
20912\end{array}$ & 1801 & 8.61 & & & \\
Food market & 2419 & 78 & 3.22 & & & \\
Farm & 1371 & 99 & 7.22 & & & \\
Pet store & 578 & 149 & 25.78 & 380.57 & 6 & $<0.001$ \\
Zoo \& & 542 & 49 & 9.04 & & & \\
aquarium & & & & & & \\
Preserved & 1785 & 65 & 3.64 & & & \\
Imported & 826 & 89 & 10.77 & & & \\
Total & 28433 & 2330 & 8.19 & & & \\
Age & & & & & & \\
categories & & & & & & \\
Adult & 27853 & 2234 & 8.02 & & & \\
Juvenile & 80 & 11 & 13.75 & 22.09 & 2 & \\
Tadpole & 388 & 55 & 14.18 & & & \\
Total & 28433 & 2330 & 8.19 & & & \\
\hline & & & & & & \\
\hline
\end{tabular}

Chytrid has been reported as pathogenic and virulent at temperatures between 12 to $27^{\circ} \mathrm{C}$ (Skerratt et al., 2007), and Swei et al. (2011) showed that $B d$ infection occurs at ranges from 330 meters above sea level in Philippines to 1,949 meters above sea level in Indonesia. A study conducted by Dahanukar et al. (2013) also reported Bd within the above-mentioned limits of temperature and elevation. These results are consistent with the higher incidence of chytrid in wild amphibians during cooler months that have been widely reported in past studies (Aplin, 2000; Kriger \& Hero, 2007; McDonald et al., 2005; Retallick et al., 2004; Woodhams \& Alford, 2005). Kusrini et al. (2008) called for a survey in the mountainous areas because declines of amphibian populations at high elevations associated with cooler temperatures have 
been linked to $B d$ (Skerratt et al., 2007). The reported prevalence of chytrid among wild Asian amphibians could be underestimated, caused by surveys being conducted at lower elevation sites associated with high temperatures. However, Savage et al. (2011) detected no significant regional or altitudinal difference in $B d$ prevalence for the 127 samples across 11 localities in Peninsular Malaysia that they surveyed. The reported prevalence of chytrid among wild Asian amphibians could not be entirely underestimated and linked to survey bias, i.e. higher number of surveys being conducted at lower elevation sites associated with high temperatures because new evidence from Russell et al. (2019) stresses the critical role of low elevation in the spread and persistence of chytrid. These inconsistencies could possibly be addressed by an increased survey effort with random and representative samples of amphibian species across all habitats in Asia.

\section{Origin of $B d$ in Asia}

East Asia has been found to be the geographic hotspot for $B d$ biodiversity and the original source of chytrid infecting amphibians worldwide (O'Hanlon et al., 2018). They also showed that the emergence of the pathogenic BdGPL (Global Panzootic Lineage) in the early 20th century coincides with the global expansion of commercial trade in amphibians. Based on the lower prevalence of $B d$ and the absence of mass die-off events or chytridiomycosis epidemics in Asia, Swei et al. (2011) suggested a thorough historical analysis of museum records. Tests on museum specimens indicate that the $B d$ has been present in Asia for more than 100 years (Fong et al., 2015; Goka et al., 2009; Zhu et al., 2014a), suggesting that chytrid fungus is native in Asia.

Bai et al. (2010) suggested the possibility that native frogs with chytridiomycosis had already died before the survey was conducted. This is unlikely, however, because several studies have found no clinical signs of chytridiomycosis despite the presence of $B d$. No clinical signs may be due to species-specific susceptibility to chytrid infection (Blaustein et al., 2005; Rollins-Smith et al., 2006), thus some native amphibian species may display innate resistance to chytridiomycosis and act as reservoir hosts. However, studies on horizontal transmission of chytridiomycosis in Asia are still lacking. Analysis conducted by Goka et al. (2009) on the isolates of $B d$ from Asia showed sufficient genetic differentiation to implicate that $B d$ is endemic in Asia. Most of the 26 haplotypes detected by Goka et al. (2009) in Japan have never been reported in other countries. Molur et al. (2015) suggest that there is a single widespread haplotype of $B d$ in the Western Ghats (India), which is identical to the Asian ( $100 \%$ similar to the strain collected from Japan and China) endemic strain as argued by Dahanukar et al. (2013). Savage et al. (2011) also argued that $B d$ is endemic to Peninsular Malaysia. Bai et al. (2012) hypothesised that the haplotype of $B d$ in Asia belongs to a lineage that has a unique association with Asian amphibians, and differs significantly from the global panzootic lineage, BdGPL (James et al., 2009). A recent study traced the source of $B d$ to the Korean peninsula, where one lineage exhibits the genetic hallmarks of an ancestral population that seeded the panzootic (O'Hanlon et al., 2018).
Our meta-analysis shows that a higher percentage of $B d$-positive results in the samples collected from pet stores and imported frogs than wild counterparts, suggesting that the international and domestic trades could be responsible for the dispersal and transport of $B d$ (Daszak et al., 1999; Fisher \& Garner, 2007; Skerratt et al., 2007; Weldon et al., 2004). A higher percentage of freeranging American bullfrogs (Lithobates catesbeianus) and African clawed frogs (Xenopus laevis) with Bd infection compared to native amphibians is consistent with the prevalence reported in other countries where they have been introduced (Cunningham et al., 2005; Garner et al., 2005, 2006; Hanselmann et al., 2004; Mazzoni et al., 2003). These two frog species also appear to be relatively resistant to clinical chytridiomycosis (Daszak et al., 2004), and are ideal carriers for introducing $B d$ into uninfected regions in the world. In support of this argument, Borzee et al. (2017) showed that $B d$ prevalence is the highest at sites in Korea where L. catesbeianus is found, implying that this exotic species serves as potential reservoir. However, they also found a negative correlation between the presence of this exotic frog species and a native Korean species. Goka et al. (2009) also found that the incidence of the fungus in naturalised individuals of $L$. catesbeianus is much higher than that in native Japanese species. Nevertheless, the authors found no trend suggesting that the presence of the fungus in amphibians increases around habitats where infected individuals of $L$. catesbeianus were detected. On the contrary, the study found that sites where native species were infected were not adjacent to sites of infected $L$. catesbeianus.

Molur et al. (2015) reported slightly higher loads of $B d$ zoospore in samples from Western Ghats (India) than found in previous studies conducted by Nair et al. (2011) and Dahanukar et al. (2013) in the same area, and in Asia (Swei et al., 2011) in general, thereby identifying a widespread $B d$ infection as a plausible threat in the future. Despite the uncertain nature of the pathogenicity of the currently circulating strain of $B d$ in India and East Asia, Molur et al. (2015) called for continuous surveillance of amphibian populations because there are other stressors that trigger $B d$ infection.

\section{Environmental and geographical factors limiting $B d$ distribution}

Several studies (Lötters et al., 2009; Puschendorf et al., 2009; Rödder et al., 2009; Ron, 2005; Swei et al., 2011) have modelled the distribution of $B d$ in Asia based on different environmental factors such as temperature and seasonality of precipitation. The species distribution models used in these papers suggests that $B d$-suitable conditions are widely distributed across Asia. However, suitable environmental conditions do not guarantee the presence of $B d$ because dispersal and persistence abilities of $B d$ also play a crucial role. In an analysis conducted on 3,363 samples from 15 Asian countries, Swei et al. (2011) suggest that $B d$ is much less widespread than predicted by models. Models contain uncertainties; hence we collected data from $B d$-positive localities across Asia to understand the suitable range of temperature and rainfall. The prevalence of diseases at different elevations is correlated with temperature (Grundler et al., 2012), 
and Piotrowski et al., (2004) showed that $B d$ can survive in the temperature range of $4-28^{\circ} \mathrm{C}$ with an optimum growth temperature of $17-25^{\circ} \mathrm{C}$. Our meta-analysis is consistent with their findings.

We found that fallow land and built-up areas, which are expectedly close to human settlement, have higher prevalence rates than forest and vegetation categories, which are more isolated from human settlements (Fig. 5). Proximity to human habitation and land cover patterns influence amphibian distribution, susceptibility and exposure to diseases (El Mouden et al., 2011; Pauza et al., 2010; Saenz et al., 2015; Thorpe et al., 2018a, b; Van Sluys \& Hero, 2009). Our finding is consistent with previous studies that suggest that areas with little human disturbance may have lower $B d$ prevalence compared to areas with high anthropogenic disturbances. However, what factors are responsible for this are still unknown (Becker \& Zamudio, 2011; Lane \& Burgin, 2008) and beyond the scope of this review, but it would not be overstated to say anthropogenic activities can possibly act as one of the key factors for $B d$ infection.

We have attempted to define the most suitable environmental and geographical range for $B d$ infection in Asia; however, our conclusions could be skewed because of missing information caused by the large geographic bias in the location of chytridiomycosis studies across Asia.

\section{CONCLUSIONS}

Within the scope of this review we have attempted to provide an overview of $B d$ infection, its spread, and its impacts on amphibians in Asia, but we did not include Batrachochytrium salamandrivorans (Bsal) in the review. It should be mentioned that Bsal has been present in Asian salamanders both in wild and museum samples for over 150 years (Laking et al., 2017; Martel et al., 2014). To date, the decline of an amphibian population due to $B d$ has not been reported from Asia. However, we advocate for longterm survey and monitoring strategies across countries with a higher potential of $B d$ infection in future. Countries where studies on $B d$ have not been conducted as of yet should focus on assessing its baseline immediately. We also recommend more research on the transmission of $B d$ infection across amphibian populations and between amphibian species to better understand the potential for chytrid epidemics in Asia.

\section{Availability of data and materials}

All data extracted and analysed during this review study are available in this published article (and its supplementary information files).

\section{Competing interests}

The authors declare that they have no competing interests.

\section{Funding}

The authors declare that the review was conducted in the absence of any commercial or financial support from any institution or organisation.

\section{Authors' contributions}

MSI planned the review and initially designed it. MMR extensively contributed to revise the initial design. MMR, MS and MFR reviewed literature, extracted and analysed data, and generated figures. MMR and MKB wrote the manuscript. All authors provided their comments and approved the final manuscript.

\section{ACKNOWLEDGEMENTS}

We would like to acknowledge Dr. Joyce E. Longcore for reviewing an earlier version of the manuscript, significant improvements to the manuscript were made following her advice. Thanks to Dr. Todd R. Lewis for providing some $B d$-positive location data. We also would like to thank Md. Mahabub Alam and Nusrat Jahan Urmy for their support during manuscript preparation. We express gratitude to two anonymous reviewers for their insightful comments and suggestions on the earlier version of the manuscript.

\section{REFERENCES}

Aplin, K. (2000). Chytridiomycosis in southwest Australia: historical sampling documents the date of introduction, rates of spread and seasonal epidemiology, and sheds new light on chytrid ecology. Paper presented at the Getting the Jump! On Amphibian Disease: Conference and Workshop Compendium. Cairns, August 2000.

Bai, C., Garner, T. W. \& Li, Y. (2010). First evidence of Batrachochytrium dendrobatidis in China: discovery of chytridiomycosis in introduced American bullfrogs and native amphibians in the Yunnan Province, China. EcoHealth 7, 127-134.

Bai, C., Liu, X., Fisher, M. C., Garner, T. W. \& Li, Y. (2012). Global and endemic Asian lineages of the emerging pathogenic fungus Batrachochytrium dendrobatidis widely infect amphibians in China. Diversity and Distributions 18, 307318.

Bataille, A., Fong, J. J., Cha, M., Wogan, G. O., Baek, H. J., Lee, H., Min, M. S. \& Waldman, B. (2013). Genetic evidence for a high diversity and wide distribution of endemic strains of the pathogenic chytrid fungus Batrachochytrium dendrobatidis in wild Asian amphibians. Molecular Ecology 22, 4196-4209.

Becker, C. G. \& Zamudio, K. R. (2011). Tropical amphibian populations experience higher disease risk in natural habitats. Proceedings of the National Academy of Sciences 108, 9893-9898.

Berger, L., Speare, R., Daszak, P., Green, D. E., Cunningham, A. A., Goggin, C. L., Slocombe, R., Ragan, M. A., Hyatt, A. D. \& McDonald, K. R. (1998). Chytridiomycosis causes amphibian mortality associated with population declines in the rain forests of Australia and Central America. Proceedings of the National Academy of Sciences USA 95, 9031-9036.

Blaustein, A. R., Romansic, J. M., Scheessele, E. A., Han, B. A., Pessier, A. P. \& Longcore, J. E. (2005). Interspecific variation in susceptibility of frog tadpoles to the pathogenic fungus Batrachochytrium dendrobatidis. Conservation Biology 19, 1460-1468.

Borzée, A., Kosch, T. A., Kim, M. \& Jang, Y. (2017). Introduced bullfrogs are associated with increased Batrachochytrium 
dendrobatidis prevalence and reduced occurrence of Korean treefrogs. PLOS ONE 12, e0177860.

Bower, D. S., Lips, K. R., Schwarzkopf, L., Georges, A. \& Clulow, S. (2017). Amphibians on the brink. Science 357, 454-455.

Brown, J. L. (2014). SDM toolbox: a python-based GIS toolkit for landscape genetic, biogeographic and species distribution model analyses. Methods in Ecology and Evolution 5, 694-700.

Crawford, A. J., Lips, K. R. \& Bermingham, E. (2010). Epidemic disease decimates amphibian abundance, species diversity, and evolutionary history in the highlands of central Panama. Proceedings of the National Academy of Sciences USA 107, 13777-13782.

Cunningham, A., Garner, T., Aguilar-Sanchez, V., Banks, B., Foster, J., Sainsbury, A., Perkins, M., Walker, S., Hyatt, A. \& Fisher, M. (2005). Emergence of amphibian chytridiomycosis in Britain. Veterinary Record 157, 386-387.

Dahanukar, N., Krutha, K., Paingankar, M.S., Padhye, A. D., Modak, N. \& Molur, S. (2013). Endemic Asian chytrid strain infection in threatened and endemic anurans of the northern Western Ghats, India. PLOS ONE 8, e77528.

Daszak, P., Berger, L., Cunningham, A. A., Hyatt, A. D., Green, D. E. \& Speare, R. (1999). Emerging infectious diseases and amphibian population declines. Emerging Infectious Diseases 5, 735.

Daszak, P., Strieby, A., Cunningham, A. A., Longcore, J., Brown, C. \& Porter, D. (2004). Experimental evidence that the bullfrog (Rana catesbeiana) is a potential carrier of chytridiomycosis, an emerging fungal disease of amphibians. Herpetological Journal 14, 201-208.

El Mouden, E. H., Slimani, T., Donaire, D., FernándezBeaskoetxea, S., Fisher, M. C. \& Bosch, J. (2011). First record of the chytrid fungus Batrachochytrium dendrobatidis in North Africa. Herpetological Review 42, 71-75.

Fick, S. E. \& Hijmans, R. J. (2017). WorldClim 2: new 1-km spatial resolution climate surfaces for global land areas. International Journal of Climatology 37, 4302-4315.

Fisher, M. C. (2009). Endemic and introduced haplotypes of Batrachochytrium dendrobatidis in Japanese amphibians: sink or source? Molecular Ecology 18, 4731-4733.

Fisher, M. C. \& Garner, T. W. (2007). The relationship between the emergence of Batrachochytrium dendrobatidis, the international trade in amphibians and introduced amphibian species. Fungal Biology Reviews 21, 2-9.

Fong, J. J., Cheng, T. L., Bataille, A., Pessier, A. P., Waldman, B. \& Vredenburg, V. T. (2015). Early 1900s detection of Batrachochytrium dendrobatidis in Korean amphibians. PLOS ONE 10, e0115656.

Garner, T. W., Perkins, M. W., Govindarajulu, P., Seglie, D., Walker, S., Cunningham, A. A. \& Fisher, M. C. (2006). The emerging amphibian pathogen Batrachochytrium dendrobatidis globally infects introduced populations of the North American bullfrog, Rana catesbeiana. Biology Letters 2, 455-459.

Garner, T. W., Walker, S., Bosch, J., Hyatt, A. D., Cunningham, A. A. \& Fisher, M. C. (2005). Chytrid fungus in Europe. Emerging Infectious Diseases 11, 1639.

Gascon, C., Collins, J. P., Moore, R. D., Church, D. R., McKay, J. E. \& Mendelson, J. R. III (eds). 2007. Amphibian Conservation Action Plan. IUCN/SSC Amphibian Specialist Group. Gland, Switzerland and Cambridge, UK. 64pp.
Goka, K., Yokoyama, J., Une, Y., Kuroki, T., Suzuki, K., Nakahara, M., Kobayashi, A., Inaba, S., Mizutani, T. \& Hyatt, A. D. (2009). Amphibian chytridiomycosis in Japan: distribution, haplotypes and possible route of entry into Japan. Molecular Ecology 18, 4757-4774.

Graham, C. H., Ferrier, S., Huettman, F., Moritz, C. \& Peterson, A. T. (2004). New developments in museum-based informatics and applications in biodiversity analysis. Trends in Ecology \& Evolution 19, 497-503.

Gründler, M. C., Toledo, L. F., Parra-Olea, G., Haddad, C. F., Giasson, L. O., Sawaya, R .J., Prado, C. P., Araujo, O. G., Zara, F. J. \& Centeno, F. C. (2012). Interaction between breeding habitat and elevation affects prevalence but not infection intensity of Batrachochytrium dendrobatidis in Brazilian anuran assemblages. Diseases of Aquatic Organisms 97, 173-184.

Hanselmann, R., Rodriguez, A., Lampo, M., Fajardo-Ramos, L., Aguirre, A. A., Kilpatrick, A. M., Rodrıguez, J. P. \& Daszak, P. (2004). Presence of an emerging pathogen of amphibians in introduced bullfrogs Rana catesbeiana in Venezuela. Biological Conservation 120, 115-119.

James, T. Y., Litvintseva, A. P., Vilgalys, R., Morgan, J. A., Taylor, J. W., Fisher, M. C., Berger, L., Weldon, C., du Preez, L. \& Longcore, J. E. (2009). Rapid global expansion of the fungal disease chytridiomycosis into declining and healthy amphibian populations. PLoS Pathogens 5, e1000458.

Kriger, K. M. \& Hero, J. M. (2007). The chytrid fungus Batrachochytrium dendrobatidis is non-randomly distributed across amphibian breeding habitats. Diversity and Distributions 13, 781-788.

Kusrini, M., Skerratt, L., Garland, S., Berger, L. \& Endarwin, W. (2008). Chytridiomycosis in frogs of Mount Gede Pangrango, Indonesia. Diseases of Aquatic Organisms 82, 187-194.

Laking, A. E., Ngo, H. N., Pasmans, F., Martel, A., \& Nguyen, T. T. (2017). Batrachochytrium salamandrivorans is the predominant chytrid fungus in Vietnamese salamanders. Scientific Reports 7, 44443.

Lane, A. \& Burgin, S. (2008). Comparison of frog assemblages between urban and non-urban habitats in the upper Blue Mountains of Australia. Freshwater Biology 53, 2484-2493.

Lips, K. R. (2016). Overview of chytrid emergence and impacts on amphibians. Philosophical Transactions of the Royal Society B: Biological Sciences 371, 20150465.

Lips, K. R., Brem, F., Brenes, R., Reeve, J. D., Alford, R. A., Voyles, J., Carey, C., Livo, L., Pessier, A. P. \& Collins, J. P. (2006). Emerging infectious disease and the loss of biodiversity in a Neotropical amphibian community. Proceedings of the National Academy of Sciences USA 103, 3165-3170.

Lips, K. R., Diffendorfer, J., Mendelson III, J. R., \& Sears, M. W. (2008). Riding the wave: reconciling the roles of disease and climate change in amphibian declines. PLoS Biology 6(3), e72.

Lötters, S., Kielgast, J., Bielby, J., Schmidtlein, S., Bosch, J., Veith, M., Walker, S. F., Fisher, M. C. \& Rödder, D. (2009). The link between rapid enigmatic amphibian decline and the globally emerging chytrid fungus. EcoHealth 6, 358-372.

Martel, A., Blooi, M., Adriaensen, C., Van Rooij, P., Beukema, W., Fisher, M. C., Farrer, R. A., Schmidt, B. R., Tobler, U., Goka, $K$. et al. (2014). Recent introduction of a chytrid fungus endangers Western Palearctic salamanders. Science 346, 630-631. 
Mazzoni, R., Cunningham, A. A., Daszak, P., Apolo, A., Perdomo, E. \& Speranza, G. (2003). Emerging Pathogen in Wild Amphibians and Frogs (Rana catesbeiana) Farmed for International Trade. Emerging Infectious Diseases 9, 995998.

McDonald, K., Mendez, D., Müller, R., Freeman, A. \& Speare, R. (2005). Decline in the prevalence of chytridiomycosis in frog populations in North Queensland, Australia. Pacific Conservation Biology 11, 114-120.

Mendoza, J., Gaertner, J., Holden, J., Forstner, M. \& Hahn, D. (2011). Detection of Batrachochytrium dendrobatidis on amphibians in Pursat Province, Cambodia. Herpetological Review 42, 542-545.

Molur, S., Krutha, K., Paingankar, M. S. \& Dahanukar, N. (2015). Asian strain of Batrachochytrium dendrobatidis is widespread in the Western Ghats, India. Diseases of Aquatic Organisms 112, 251-255.

Mutschmann, F., Berger, L., Zwart, P. \& Gaedicke, C. (2000). Chytridiomycosis in amphibians--first report in Europe. Berliner und Munchener Tierarztliche Wochenschrift 113, 380-383.

Nair, A., Daniel , O., Gopalan, S., George, S., Kumar, K., Merila, J. \& Teacher, A. (2011). Infectious disease screening of Indirana frogs from the Western Ghats biodiversity hotspot. Herpetological Review 42, 554-557.

Nelson, K. E. \& Williams, C. M. (2014). Infectious disease epidemiology: theory and practice: Jones \& Bartlett Publishers.

O'Hanlon, S. J., Rieux, A., Farrer, R. A., Rosa, G. M., Waldman, B., Bataille, A., Kosch, T. A., Murray, K. A., Brankovics, B. \& Fumagalli, M. (2018). Recent Asian origin of chytrid fungi causing global amphibian declines. Science 360, 621-627.

Olson, D. \& Ronnenberg, K. (2014). Global Bd mapping project: 2014 update. Froglog 22, 17-21.

Olson, D. H., Aanensen, D. M., Ronnenberg, K. L., Powell, C. I., Walker, S. F., Bielby, J., Garner, T. W., Weaver, G. \& Fisher, M. C. (2013). Mapping the global emergence of Batrachochytrium dendrobatidis, the amphibian chytrid fungus. PLOS ONE 8, e56802.

Parto, P., Vaissi, S., Farasat, H. \& Sharifi, M. (2013). First report of chytridiomycosis (Batrachochytrium dendrobatidis) in endangered Neurergus microspilotus (Caudata: Salamandridae) in western Iran. Global Veterinaria 11, 547551.

Pauza, M. D., Driessen, M. M. \& Skerratt, L. F. (2010). Distribution and risk factors for spread of amphibian chytrid fungus Batrachochytrium dendrobatidis in the Tasmanian Wilderness World Heritage Area, Australia. Diseases of Aquatic Organisms 92, 193-199.

Phillips, S. J., Anderson, R. P. \& Schapire, R. E. (2006). Maximum entropy modeling of species geographic distributions. Ecological Modelling 190, 231-259.

Piotrowski, J. S., Annis, S. L. \& Longcore, J. E. (2004). Physiology of Batrachochytrium dendrobatidis, a chytrid pathogen of amphibians. Mycologia 96, 9-15.

Puschendorf, R., Carnaval, A. C., VanDerWal, J., Zumbado-Ulate, H., Chaves, G., Bolaños, F. \& Alford, R. A. (2009). Distribution models for the amphibian chytrid Batrachochytrium dendrobatidis in Costa Rica: proposing climatic refuges as a conservation tool. Diversity and Distributions 15, 401-408.

Retallick, R. W., McCallum, H. \& Speare, R. (2004). Endemic infection of the amphibian chytrid fungus in a frog community post-decline. PLoS Biology 2, e351.

Rödder, D., Kielgast, J., Bielby, J., Schmidtlein, S., Bosch, J., Garner, T. W., Veith, M., Walker, S., Fisher, M. \& Lötters, S. (2009). Global amphibian extinction risk assessment for the panzootic chytrid fungus. Diversity 1, 52-66.

Rollins-Smith, L. A., Woodhams, D. C., Reinert, L. K., Vredenburg, V. T., Briggs, C. J., Nielsen, P. F. \& Conlon, J. M. (2006). Antimicrobial peptide defenses of the mountain yellow-legged frog (Rana muscosa). Developmental \& Comparative Immunology 30, 831-842.

Ron, S. R. (2005). Predicting the distribution of the amphibian pathogen Batrachochytrium dendrobatidis in the New World 1. Biotropica 37, 209-221.

Rowley, J. J., Hoang, H., Le, D. T. T., Dau, V. Q., Neang, T. \& Cao, T. T. (2013). Low prevalence or apparent absence of Batrachochytrium dendrobatidis infection in amphibians from sites in Vietnam and Cambodia. Herpetological Review 44, 466-469.

Russell, I. D., Larson, J. G., von May, R., Holmes, I. A., James, T. Y., \& Rabosky, A. R. D. (2019). Widespread chytrid infection across frogs in the Peruvian Amazon suggests critical role for low elevation in pathogen spread and persistence. PloS One 14, e0222718.

Rytkönen, M. J. (2004). Not all maps are equal: GIS and spatial analysis in epidemiology. International Journal of Circumpolar Health 63, 9-24.

Saenz, D., Hall, T. L. \& Kwiatkowski, M. A. (2015). Effects of urbanization on the occurrence of Batrachochytrium dendrobatidis: do urban environments provide refuge from the amphibian chytrid fungus? Urban Ecosystems 18, 333340.

Savage, A. E., Grismer, L. L., Anuar, S., Onn, C. K., Grismer, J. L., Quah, E., Muin, M. A., Ahmad, N., Lenker, M. \& Zamudio, K. R. (2011). First record of Batrachochytrium dendrobatidis infecting four frog families from Peninsular Malaysia. EcoHealth 8, 121-128.

Scheele, B. C., Pasmans, F., Skerratt, L. F., Berger, L., Martel, A., Beukema, W., Aldemar A. Acevedo, A. A., Burrowes, P. A., Carvalho, T. et al. (2019). Amphibian fungal panzootic causes catastrophic and ongoing loss of biodiversity. Science 363, 1459-1463.

Silverman, B. W. (1986). Density Estimation for Statistics and Data Analysis (Vol. 26): CRC Press.

Skerratt, L. F., Berger, L., Speare, R., Cashins, S., McDonald, K. R., Phillott, A. D., Hines, H. B. \& Kenyon, N. (2007). Spread of chytridiomycosis has caused the rapid global decline and extinction of frogs. EcoHealth 4, 125.

Stuart, S. N., Chanson, J. S., Cox, N. A., Young, B. E., Rodrigues, A. S., Fischman, D. L. \& Waller, R. W. (2004). Status and trends of amphibian declines and extinctions worldwide. Science 306, 1783-1786.

Swei, A., Rowley, J. J., Rödder, D., Diesmos, M. L., Diesmos, A. C., Briggs, C. J., Brown, R., Cao, T. T., Cheng, T. L. \& Chong, R. A. (2011). Is chytridiomycosis an emerging infectious disease in Asia? PLoS ONE 6, e23179.

Thorpe, C. J., Lewis, T. R., Fisher, M. C., Wierzbicki, C. J., Kulkarni, S., Pryce, D., Davies, L., Watve, A. \& Knight, M. E. (2018a). Climate structuring of Batrachochytrium dendrobatidis infection in the threatened amphibians of the northern Western Ghats, India. Royal Society Open Science 5, 180211. 
Thorpe, C. J., Lewis, T. R., Kulkarni, S., Watve, A., Gaitonde, N., Pryce, D., Davies, L., Bilton, D. T. \& Knight, M. E. (2018b). Micro-habitat distribution drives patch quality for subtropical rocky plateau amphibians in the northern Western Ghats, India. PLoS ONE 13, e0194810.

Une, Y., Kadekaru, S., Tamukai, K., Goka, K. \& Kuroki, T. (2008). First report of spontaneous chytridiomycosis in frogs in Asia. Diseases of Aquatic Organisms 82, 157-160.

Van Sluys, M. \& Hero, J. M. (2009). How does chytrid infection vary among habitats? The case of Litoria wilcoxii (Anura, Hylidae) in SE Queensland, Australia. EcoHealth 6, 576-583.

Vörös, J., Satasook, C., Bates, P. \& Wangkulangkul, S. (2012). First record of the amphibian chytrid fungus, Batrachochytrium dendrobatidis in Thailand. Herpetology Notes 5, 519-521.

Vredenburg, V. T., Knapp, R. A., Tunstall, T. S. \& Briggs, C. J. (2010). Dynamics of an emerging disease drive large-scale amphibian population extinctions. Proceedings of the National Academy of Sciences USA 107, 9689-9694.

Weldon, C., Du Preez, L. H., Hyatt, A. D., Muller, R. \& Speare, R. (2004). Origin of the amphibian chytrid fungus. Emerging Infectious Diseases 10, 2100.
Woodhams, D. C. \& Alford, R. A. (2005). Ecology of chytridiomycosis in rainforest stream frog assemblages of tropical Queensland. Conservation Biology 19, 1449-1459.

Woodhams, D. C., Hyatt, A. D., Boyle, D. G. \& Rollins-Smith, L. A. (2008). The northern leopard frog Rana pipiens is a widespread reservoir species harboring Batrachochytrium dendrobatidis in North America. Herpetological Review 39, 66.

Yang, H., Baek, H., Speare, R., Webb, R., Park, S., Kim, T., Lasater, K. C., Shin, S., Son, S. \& Park, J. (2009). First detection of the amphibian chytrid fungus Batrachochytrium dendrobatidis in free-ranging populations of amphibians on mainland Asia: survey in South Korea. Diseases of Aquatic Organisms 86, 9-13.

Zhu, W., Bai, C., Wang, S., Soto-Azat, C., Li, X., Liu, X. \& Li, Y. (2014a). Retrospective survey of museum specimens reveals historically widespread presence of Batrachochytrium dendrobatidis in China. EcoHealth 11, 241-250.

Zhu, W., Xu, F., Bai, C., Liu, X., Wang, S., Gao, X., Yan, S., Li, X., Liu, Z. \& Li, Y. (2014b). A survey for Batrachochytrium salamandrivorans in Chinese amphibians. Current Zoology 60, 729-735.

Accepted: 9 December 2019

Please note that the Supplementary Materials are available via the Herpetological Journal website: https://thebhs.org/publications/the-herpetological-journal/volume-30-number2-april-2020 